\title{
Meiofaunal responses to sedimentation from an Alaskan spring bloom. II. Harpacticoid population dynamics
}

\author{
John W. Fleeger ${ }^{1}$, Thomas C. Shirley ${ }^{2}$ \\ ${ }^{1}$ Department of Zoology and Physiology, Louisiana State University, Baton Rouge, Louisiana 70803, USA \\ ${ }^{2}$ Juneau Center for Fisheries and Ocean Sciences, University of Alaska Fairbanks, Juneau, Alaska 99801, USA
}

\begin{abstract}
As previously reported, metazoan meiofaunal major taxon seasonal variation and density maxima were found to be unrelated to spring phytoplankton sedimentation over a 4 yr period in Auke Bay, Alaska. To determine how individual species responded to sedimentation, meiobenthic copepods were analysed separately and the results discussed here. The harpacticoid copepod assemblage was diverse: 35 species, of which 16 were common and abundant each field season and throughout the bay. Three species, Tachidiella cf, minuta, Danielssenia reducta Gee and Pseudameira sp., dominated collections, comprising about $60 \%$ of all individuals. Reproductive cycles in some species appeared to be related to the April-May sedimentation event. Age-structured data indicate marked changes coincident with sedimentation for 2 of the 3 predominant species. In the overwintering species $D$. reducta and $I$ cf. minuta, the proportion of copepodites increased in April and May and striking increases in the proportions of males followed in May and June annually. This pattern suggests that a cohort is produced in conjunction with spring sedimentation. Pseudameira sp. reproduced early, before spring sedimentation. Most significantly however, seasonality in population density was not obvious, and although abundances differed among years, density maxima did not co-vary with sedimentation. intensity. This suggests that harpacticoid density maxima are not tightly linked with phytodetritus and that other factors regulate abundance.
\end{abstract}

\section{INTRODUCTION}

Phytoplankton blooms and their accompanying sedimentation may have profound effects on the benthos (Townsend \& Cammen 1988). Phytoplankton during and after bloom conditions settle quickly to the bottom (Graf et al. 1982, Billett et al. 1983), and settled cells in good nutritional condition (Lenz 1977) may serve as a direct food source for surface-dwelling benthic fauna (Decho 1986, Rudnick 1989). Even though this influx is brief, it represents a considerable fraction of the annual benthic organic input (Graf et al. 1982). Potential benthic responses to phytodetritus are diverse. Population density may increase (Rudnick et al. 1985), aggregations or increases in activity are possible (Gooday 1988), metabolic energy stores are known to increase (Graf et al. 1983) and reproduction or recruitment (Townsend \& Cammen 1988) may couple with sedimentation. Metazoan associations with sedimentation have been frequently studied. Correlations between faunal density and planktonic productiv- ity or sediment pigment levels have been found spatially across environmental gradients (Pfannkuche \& Thiel 1987, Grebmeier et al. 1988). However, sedimentation within a year appears to be much more seasonal than is the change in abundance in macrofauna (Graf et al. 1983, Valderhaug \& Gray 1984).

Meiofaunal relationships with phytodetritus are even more poorly studied than those with macrofauna (Graf et al. 1982, Rudnick et al. 1985, Widbom \& Elmgren 1988). In earlier work, we found no direct evidence for sedimentation-induced changes in meiofaunal densities for major taxa, including harpacticoid copepods, in Auke Bay, Alaska (Fleeger et al. 1989). A significant concern with studies conducted at the major taxon level is that effects may be masked if species react individually. In this report we discuss the relationship between spring phytoplankton sedimentation and the population dynamics of harpacticoid copepod species collected in our earlier study. This work is part of the APPRISE (Association of Primary Production and Recruitment in a Subarctic Ecosystem) project, a 5 yr 
study with the goal of increased understanding of the linkages between physical and biological characteristics associated with the spring bloom in subarctic waters.

Harpacticoids from subtidal muds are ideal subjects for the study of sedimentation effects on meiofauna species. Their biology suggests an intimate association with phytodetritus. Harpacticoids are surficial in their sediment depth distribution (Palmer 1984), and they are able to rapidly assimilate sedimented planktonic diatoms (Decho 1986, Rudnick 1989); preliminary evidence suggests that several Auke Bay harpacticoids utilize planktonic diatoms as food (Shirley et al. 1987). Field densities have been related to standing stocks of diatoms (Montagna et al. 1983, Decho \& Fleeger 1988a), and individual species appear to have specialized prey among the assemblage of microbes available to them (Carman \& Thistle 1985, Decho 1988). Additionally, harpacticoid reproductive ecology can be monitored from field populations because relative age structure can be determined as can sex ratio in mature individuals. Females brood eggs in visible egg sacs. Harpacticoid species specific population dynamics have been studied in a number of locales, but rarely in response to environmental cues other than temperature (Hicks \& Coull 1983).

\section{METHODS}

Sampling was conducted in Auke Bay, Alaska $\left(58^{\circ} 22^{\prime} \mathrm{N}, 134^{\circ} 40^{\prime} \mathrm{W}\right)$, ca $20 \mathrm{~km}$ north of Juneau. Coyle \& Shirley (1986) discuss this bay system. Three different locations were sampled regularly for at least one field season (Fleeger et al. 1989). The most extensive collections were from East (E) Stn, $27 \mathrm{~m}$ water depth, 1985 to 1988. At E, 1985 samples were collected at about $10 \mathrm{~d}$ intervals, April to June; in 1986 samples were obtained from May to August at about 7 d intervals with an additional collection in October. In 1987 additional stations, Auke Bay Monitor (ABM), at $50 \mathrm{~m}$, and North (N), at $42 \mathrm{~m}$, were also sampled and over a longer time interval to resolve spatial and temporal variability throughout the bay. Samples were collected at about $7 \mathrm{~d}$ intervals from April to August at E, ABM and $N$, and then monthly from September through December at E and ABM. In 1988, samples from E were obtained weekly from March through June. Sample collection and treatment were similar from all years; stations and methods are discussed in Fleeger et al. (1989). Major taxa were enumerated in all samples, and copepods (adults and copepodites) were removed and later identified to state of maturity and to species (using the aids of Lang 1948 and Wells 1976). Mature copepods were sexed, and the frequency of females with egg sacs was noted. Percent copepodites (of adults and copepodites together) and percent males (of all adults) were calculated for the harpacticoid assemblage and for selected individual species.

\section{RESULTS}

Auke Bay harpacticoid copepods were diverse throughout the 1985 to 1988 collections. A total of 35 species were classified from at least one non-damaged specimen. Of these, 16 were regularly occurring and often abundant (Table 1), with others limited to a few collections or one field season. Although some abundant species were restricted to a given season (e.g. Tisbella sp. was found only in early spring), all species listed in Table 1 were found at all stations.

Three species dominated the harpacticoid assemblage in Auke Bay (Fig. 1). Tachidiella cf. minuta, Danielssenia reducta Gee and Pseudameira sp.

Table 1. Important harpacticoid copepods in Auke Bay, 1985 to 1988. Species within families are listed if they occurred frequently within a year or were found in more than one year. Abundant: densities over $1010 \mathrm{~cm}^{-2}$; common: frequently found, usually not abundant; rare: never high in abundance but regularly occurring

\begin{tabular}{|c|c|}
\hline Species & Abundance \\
\hline $\begin{array}{l}\text { Ectinosomatidae } \\
\text { Pseudobradya sp. } 1 \\
\text { Pseudobradya sp. } 2 \\
\text { unidentified sp. } \\
\text { Pseudobradya sp. } 3\end{array}$ & $\begin{array}{l}\text { Abundant in spring } \\
\text { Abundant in summer } \\
\text { Common in spring } \\
\text { Common after } 1985\end{array}$ \\
\hline $\begin{array}{l}\text { Tachididae } \\
\text { Danielssenia typica Boech, } \\
1872 \\
\text { Danielssenia reducta Gee, } \\
1988\end{array}$ & $\begin{array}{l}\text { Common } \\
\text { Very abundant }\end{array}$ \\
\hline $\begin{array}{l}\text { Tisbidae } \\
\text { Tachidiella cf. minuta } \\
\text { Tisbella sp. }\end{array}$ & $\begin{array}{l}\text { Very abundant } \\
\text { Common early spring }\end{array}$ \\
\hline $\begin{array}{l}\text { Thalestridae } \\
\qquad \text { Dactylopodella sp. }\end{array}$ & Rare \\
\hline $\begin{array}{l}\text { Diosaccidae } \\
\text { Haloschizopera sp. } \\
\text { Stenhelia (Delavalia) } \\
\text { normani T. Scott, } 1905\end{array}$ & $\begin{array}{l}\text { Common } \\
\text { Rare }\end{array}$ \\
\hline $\begin{array}{l}\text { Ameiridae } \\
\text { Proameira signata Por, } 1964 \\
\text { Proameira sp. } \\
\text { Pseudameira sp. }\end{array}$ & $\begin{array}{l}\text { Common } \\
\text { Abundant } \\
\text { Very abundant }\end{array}$ \\
\hline $\begin{array}{l}\text { Cletodidae } \\
\quad \text { Cletodes cf. latirostis }\end{array}$ & Common \\
\hline $\begin{array}{l}\text { Laophontidae } \\
\quad \text { Normanella aberans Bodin, } \\
1968\end{array}$ & Rare \\
\hline
\end{tabular}



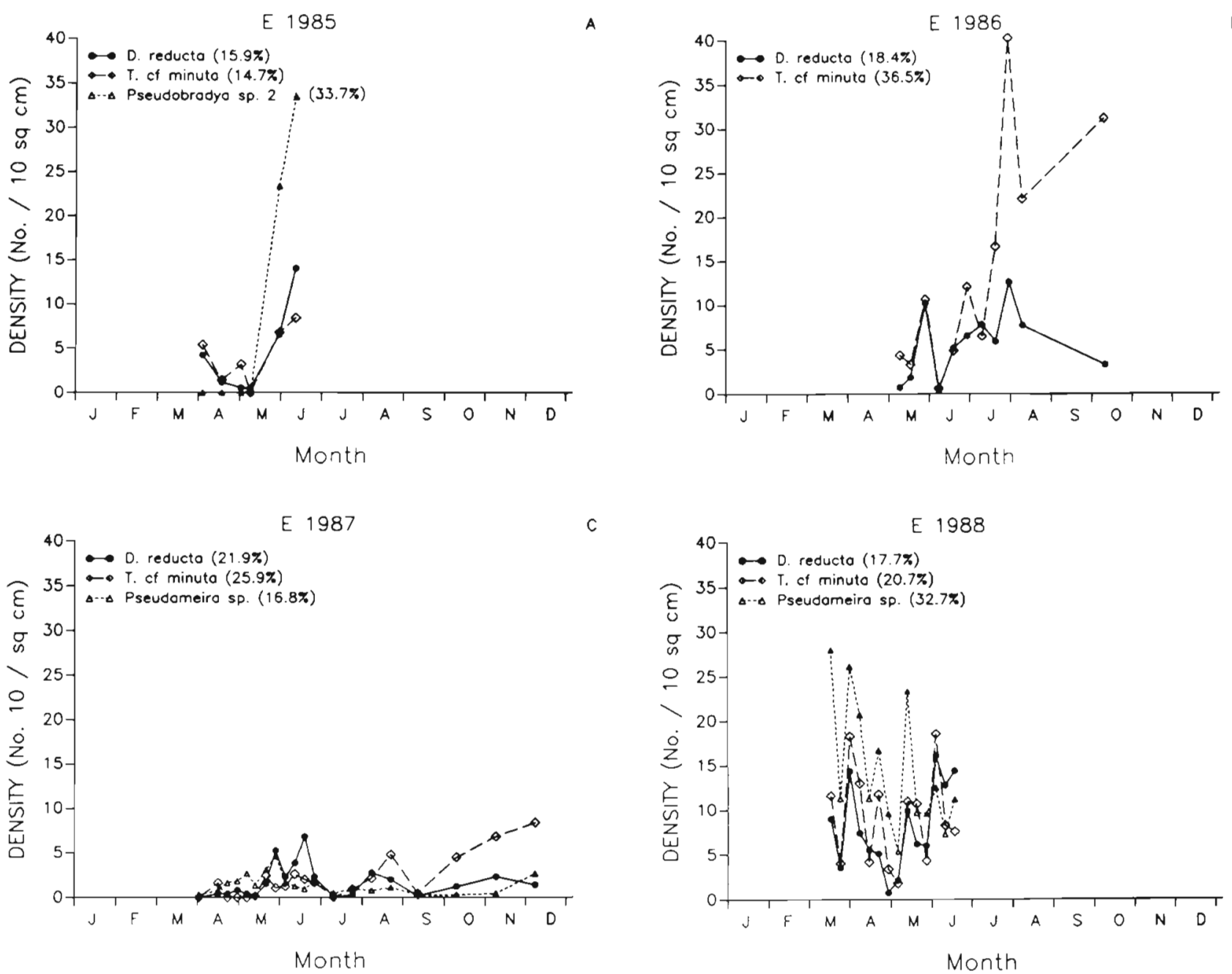

Fig. 1. Harpacticoid species densities (ind. $10 \mathrm{~cm}^{-2}$ ) at East Station, 1985 to 1988 (A to D respectively). Numbers in parentheses represent the percent composition of that species in the assemblage for that year

exceeded 10 ind. $10 \mathrm{~cm}^{-2}$ in abundance at some time in all years except 1987 at $E$ (in 1987 they were again the most abundant, but density was relatively low). In 1988 and 1987, these 3 comprised 71 and $56 \%$ of the copepod assemblage respectively (see Figs. 1 and 2 for individual species composition). In $1987 \mathrm{~T}$. cf. minuta and $D$. reducta were the most abundant species at all stations (Figs. 1 and 2). Pseudameira sp. was less abundant in 1985 and 1986, comprising less than $10 \%$ of the fauna, but very abundant in 1988, comprising about $33 \%$ of all harpacticoids. D. reducta and T. cf. minuta made up $53 \%$ of all harpacticoids in 1986, and with Pseudobradya sp. 2 (the only other species to ever exceed 10 ind. $10 \mathrm{~cm}^{-2}$ ), these 3 comprised $64 \%$ of all copepods in 1985 .

Yearly patterns of species abundance were individualized. In 1985 and 1986, densities for most species were low in April, but slightly increased into June and July. In both years, a single species (Pseudobradya sp. 2 in 1985 and Tachidiella cf. minuta in 1986), exhibited sustained growth, increasing greatly in a short period of time. In 1987 densities remained low for all species at all stations and only $T$. cf. minuta exceeded 10 ind. $10 \mathrm{~cm}^{-2}$ on one collection date at $N$ (Fig. 2). Perhaps because of a high degree of spatial variability, densities in 1988 fluctuated greatly between dates for all 3 species, with no sustained increases for individual species. $T$. cf. minuta was most abundant overall, comprising $28 \%$ of all harpacticoids, and was slightly more predominant at deeper stations. No predictable, seasonal, 'population bloom' increases were found for any species, nor was any significant large-scale spatial variability apparent at the stations sampled in Auke Bay.

Sex ratios and age structure of harpacticoids (at the major taxon level) varied through the year at $E$, in a seasonally consistent pattern. Percent males (of total adults) increased during the spring (Fig. 3A). In 1985, 1986 and 1988, the increase began in early May and lasted until mid-June. In 1987, the increase was earlier 

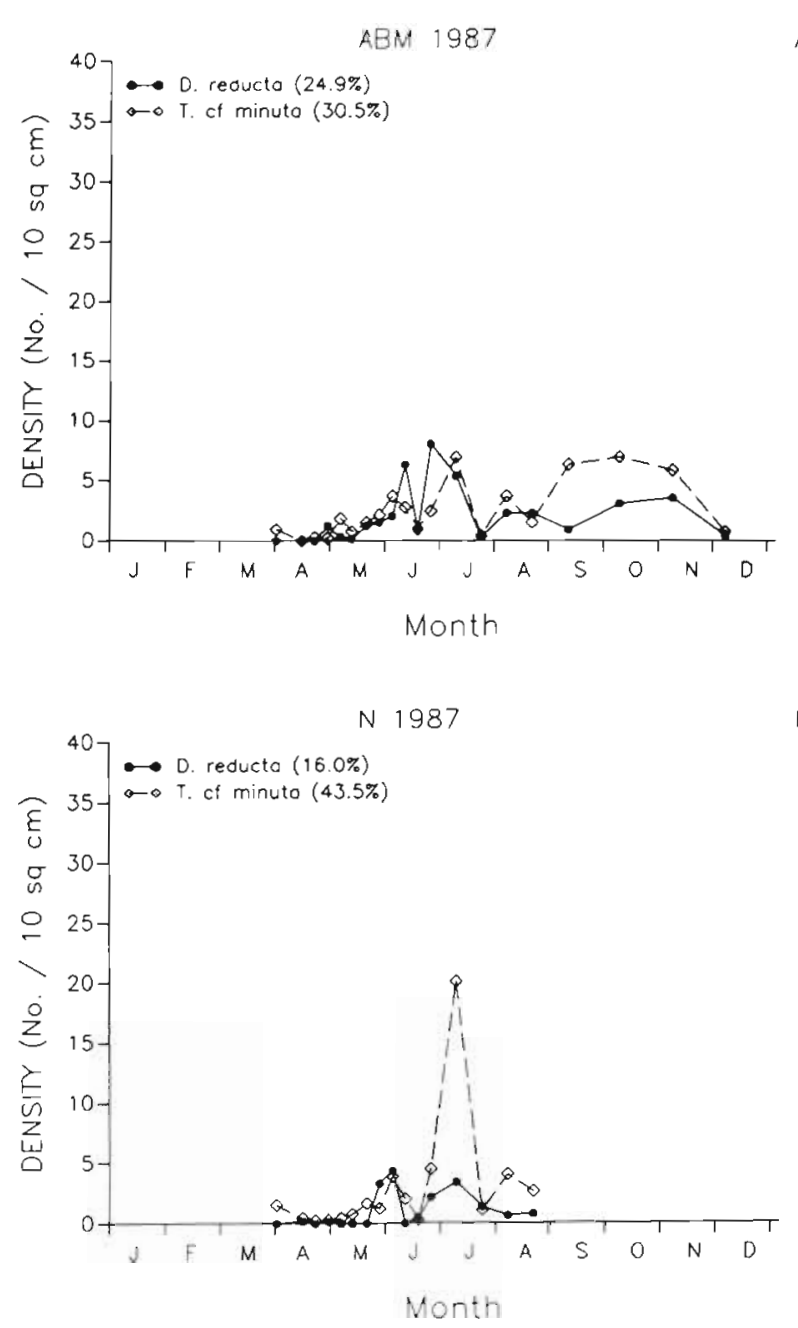

Fig. 2. Harpacticoid species densities (ind. $10 \mathrm{~cm}^{-2}$ ) at (A) Auke Bay Monitor Station and (B) North Station. Numbers in parentheses represent the percent composition of that species in the assemblage at that station

(April) and brief, but pronounced. During the remainder of the year, percent males tended to remain high in the summer but gradually decrease in the fall. Percent copepodites (of the total adults and copepodites together) also tended to increase during the spring season, but with a great deal more interannual variability (Fig. 3B). Increases took place in 1985 and 1986 during April or May. In 1987 values decreased during this time. In 1988, percent copepodites started high (50 to $60 \%$ ), and decreased as the season progressed. During summer and fall, values tended to fluctuate greatly, but generally increased in the fall.

The predominant harpacticoids in Auke Bay have seasonal reproductive cycles which together can account for the major taxon age-specific data. Unfortunately, females did not reliably retain egg sacs (egg sacs were inconsistently dislodged during sample preparation and sorting) and data are not reported here. Nevertheless, Tachidiella cf. minuta and Danielssenia
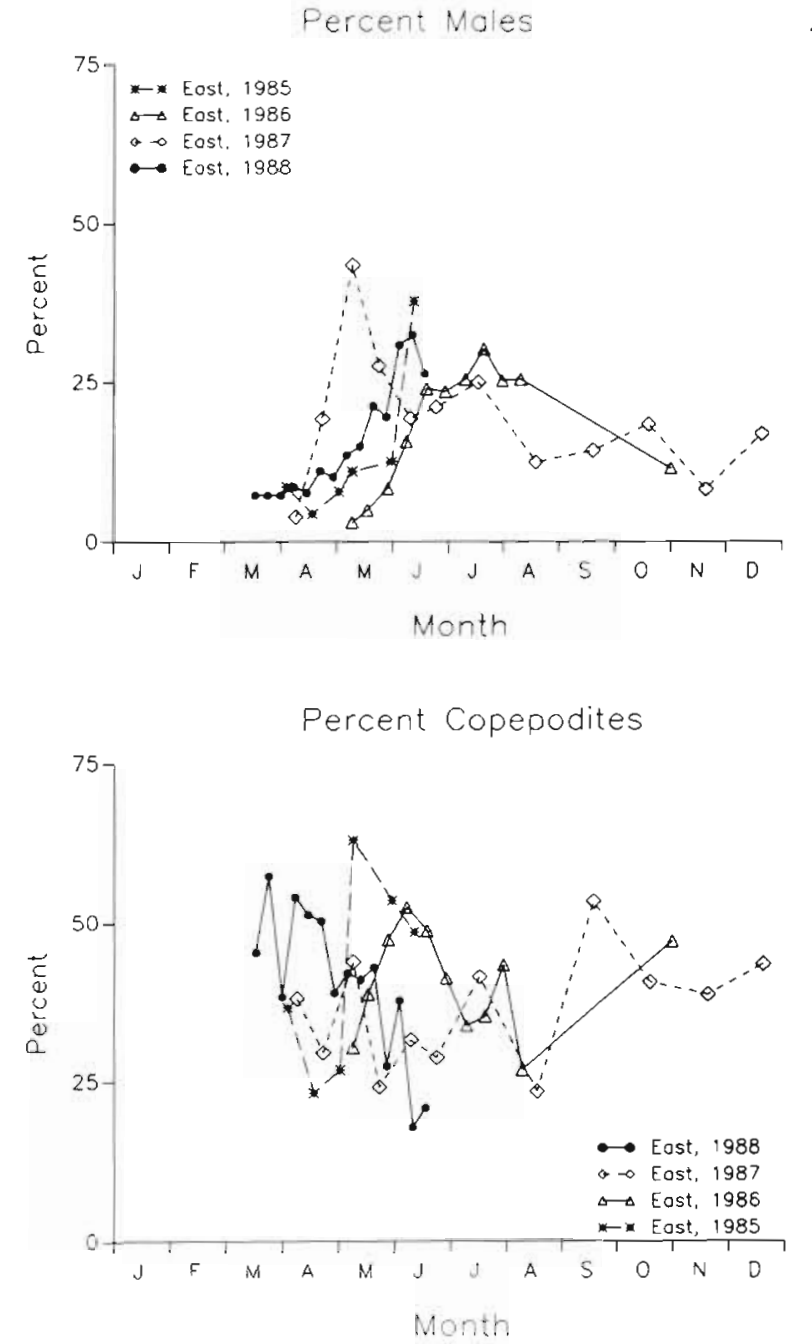

Fig. 3. (A) Percent males and (B) percent copepodites for all harpacticoids combined at East Station, 1985 to 1988

reducta (the 2 most abundant species) appear to overwinter as adult females (Figs. 4 and 5 indicate that males were rare in the early spring), and some ovigerous females were present for most species in April. $D$. reducta and $T$. cf. minuta population dynamics were similar (Figs. 4 and 5). Percent copepodites increased beginning in April for both species. Increases in percent males followed in May and into early June. Temporal variability for both species was high in 1987 when few specimens were available due to low population densities. These spring trends were independent of location in Auke Bay as values for ABM and $N$ (summed together due to low sample sizes), were very similar to $E$ in 1987 (Fig. 6). Values of each index for each species declined by July, then fluctuated before a further decline into the late fall and winter.

Pseudameira sp. probably reproduced early in the year (March or before). Only data for 1988 is presented due to low sample sizes in other years (Fig. 7). The 


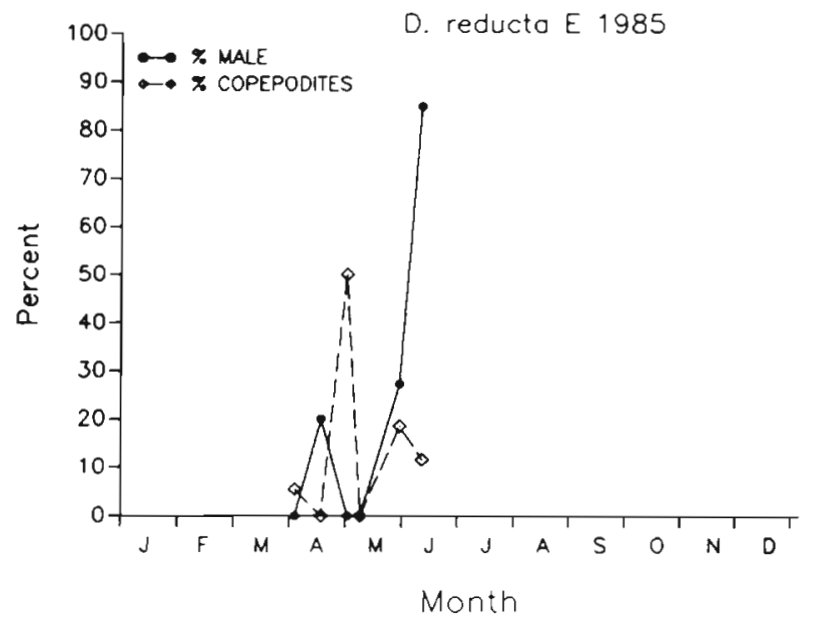

D. reducta E 1987

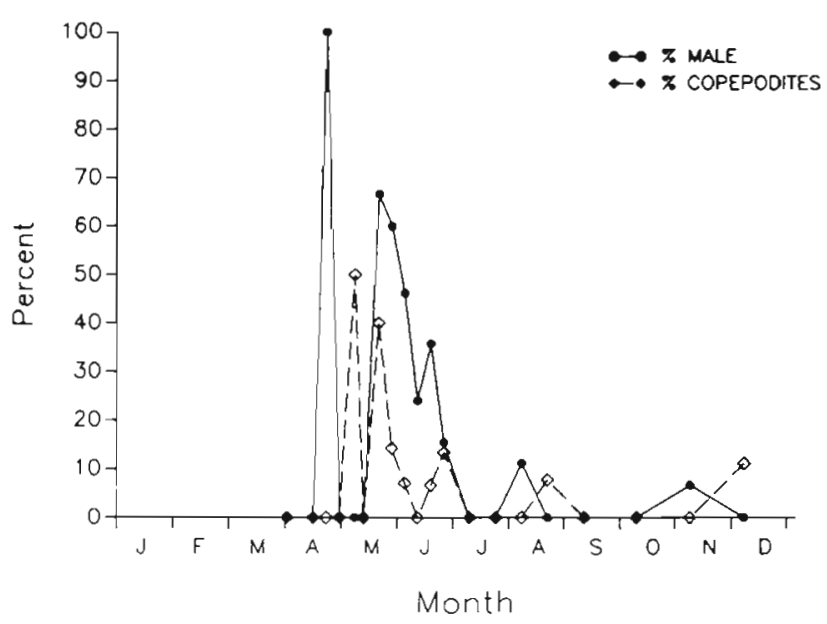

D. reducta $E 1986$

B
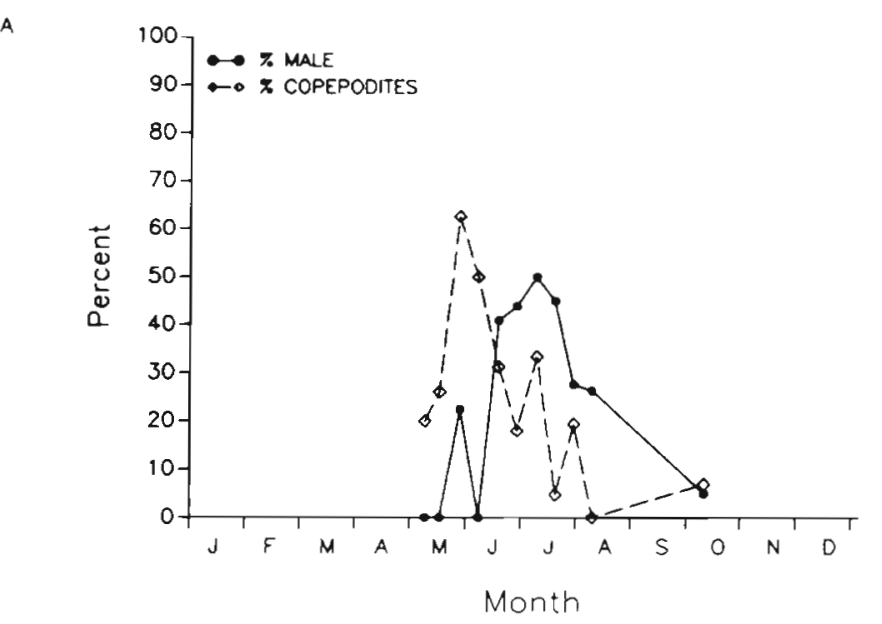

C

D. reducta $E 1988$

D

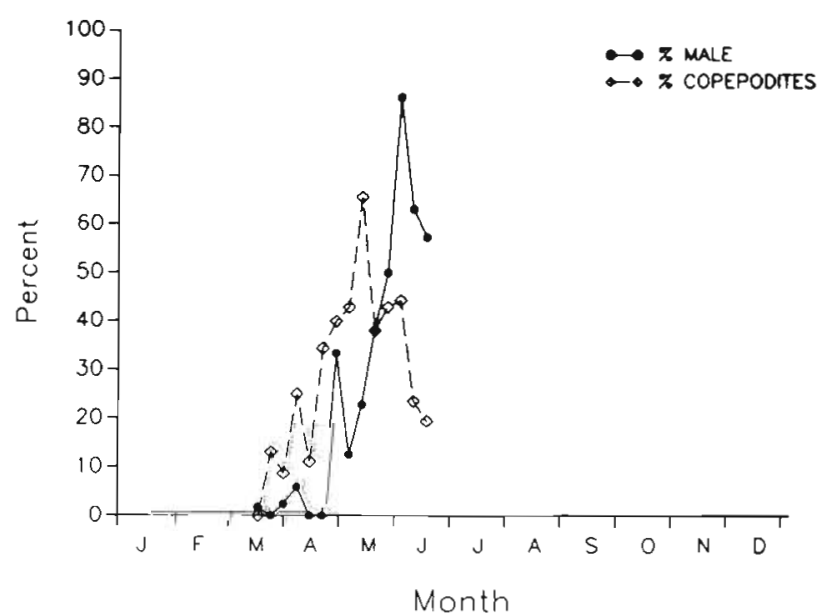

Fig. 4. Danielssenia reducta. Percent males and percent copepodites at East Station, 1985 to 1988 (A to D respectively)

percent copepodites was highest in April, and declined through June (explaining the major taxon decrease in copepodites during the spring of 1988). By the end of July, few if any copepodites were present. Sex ratio did not vary predictably, but males decreased as the summer progressed.

\section{DISCUSSION}

Spring phytoplankton blooms and accompanying chlorophyll (chl) a and carbon sedimentation appear to be a predictable, annual events in Auke Bay (Ziemann et al. 1988). Chl a sedimentation occurs throughout the spring, but the majority reaches the bottom in early May. Total, or cumulative, sedimentation through June varies from year to year however. In the 1985, 1986 and 1987 spring seasons, chl a fluxes of about 500 to $600 \mathrm{mg}$ $\mathrm{m}^{-2}$ reached the bottom; 1988 was low with a flux of about $300 \mathrm{mg} \mathrm{m}^{-2}$ (Fleeger et al. 1989). Metazoan meiofauna major taxa did not correlate well to this pattern. Densities were not as seasonal as was sedimentation, and abundance maxima among years did not correspond to the pattern of sedimentation intensity.

The densities of individual harpacticoid species were also poorly related to sedimentation events. Three species dominated collections; however, no strong evidence for seasonality in density was found. Tachidiella cf. minuta increased in total density in June 1986, but not in other years, and Pseudobradya sp. 2 reached high densities only in May 1985. Our sampling was concentrated around the sedimentation event (March to June), but we doubt that density peaks with time lags between sedimentation and population responses occurred annually outside our sampling window. Developmental times for harpacticoids are strongly temperature dependent, and although data are rare at low temperatures (Hicks \& Coull 1983), a minimal estimate of generation time at Auke Bay summer tem- 
$T$ cf minuta $E 1985$

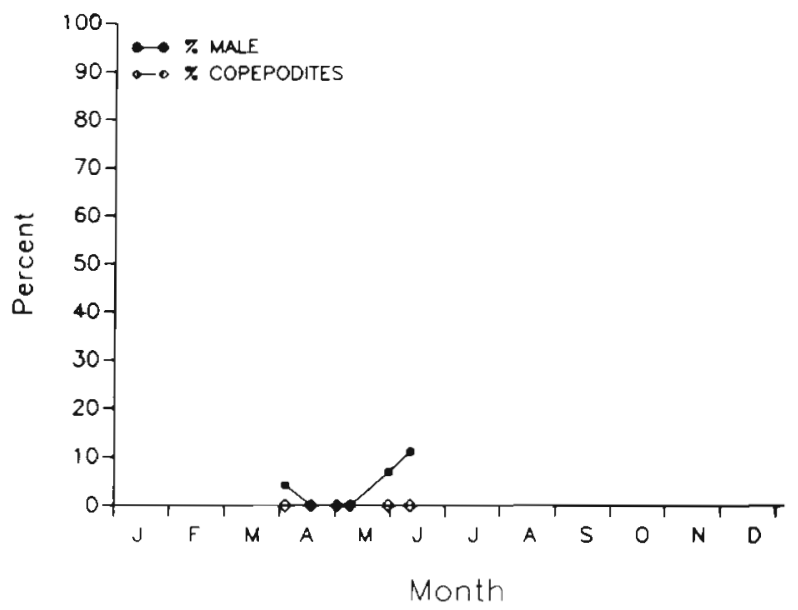

T. of minuto $E 1987$

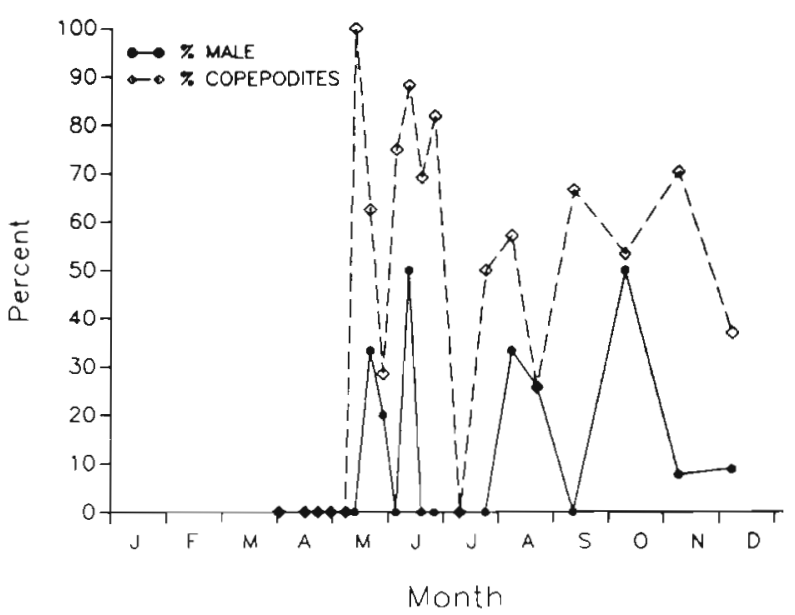

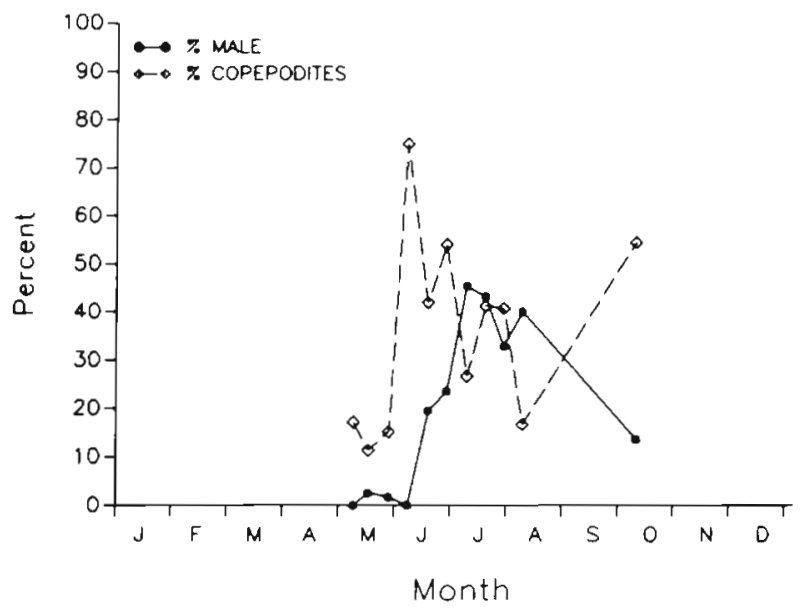

c

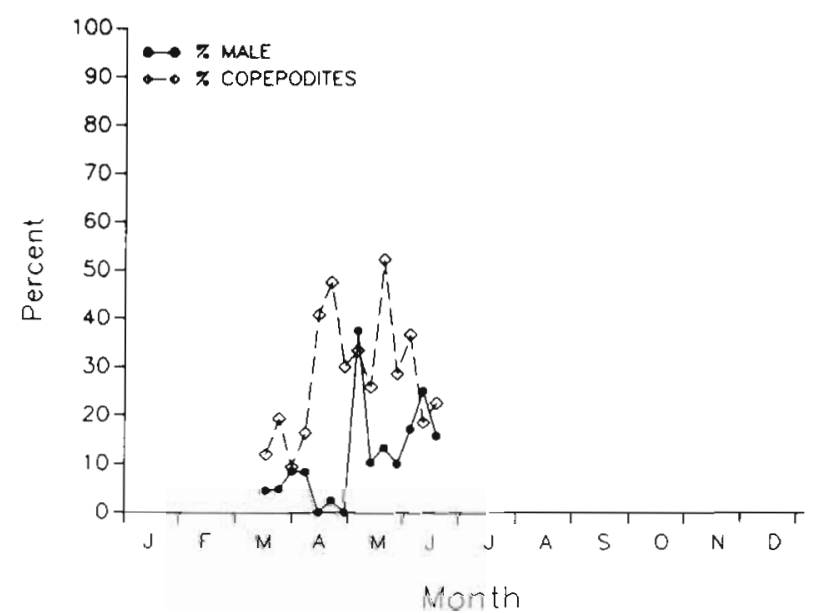

Fig. 5. Tachidiella cf. minuta. Percent males and percent copepodites at East Station, 1985 to 1988 (A to D respectively)

peratures $\left(5\right.$ to $7^{\circ} \mathrm{C}$ ) is on the order of $30 \mathrm{~d}$ (Palmer \& Coull 1980). Thus we sampled for the length of time necessary to complete approximately one generation from the onset of the sedimentation event each year but for longer times in 1986 and 1987. High fall densities for $T$. cf. minuta were found in some years ( $E 1986$ in October, E 1987 in December and N 1987 in July). However, it is difficult to attribute peaks in other seasons to events in the spring, and sampling in late summer did not reveal time lags closely liked to the sedimentation event. The significant finding remains; no dominant species responded annually within approximately one generation of the sedimentation event.

Demographic data, on the other hand, was not randomly or wildly variable from date to date or among years throughout Auke Bay. Harpacticoid sex ratio was highly seasonal (Fig. 3). The percent males for all harpacticoids combined increased through May in con- junction with the onset of sedimentation (in $1987 \mathrm{chl} a$ sedimentation was slightly early [Fleeger et al. 1989], as was the rise in percent males). Percent copepodites for all harpacticoids combined also varied with season, but in a less predictable fashion. The 3 predominant species contributed disproportionately to these patterns. Tachidiella cf. minuta and Danielssenia reducta had similar reproductive tendencies, and appeared to reproduce in the spring following an overwintering period. Distinct increases in copepodites occurred in April, and males increased in May and June. These 2 species together accounted for the seasonal increase in percent males of all harpacticoids. Percent copepodites in 1988 was influenced by Pseudameira sp. (a fall or winter reproducer) with its declining proportion of copepodites through the spring (Fig. 7). Thus, the timing of certain key species influenced the major taxon values, and for 2 of the 3 species the timing of recruitment (as suggested by increases in the relative pro- 
D. reducto $A B M, N 1987$

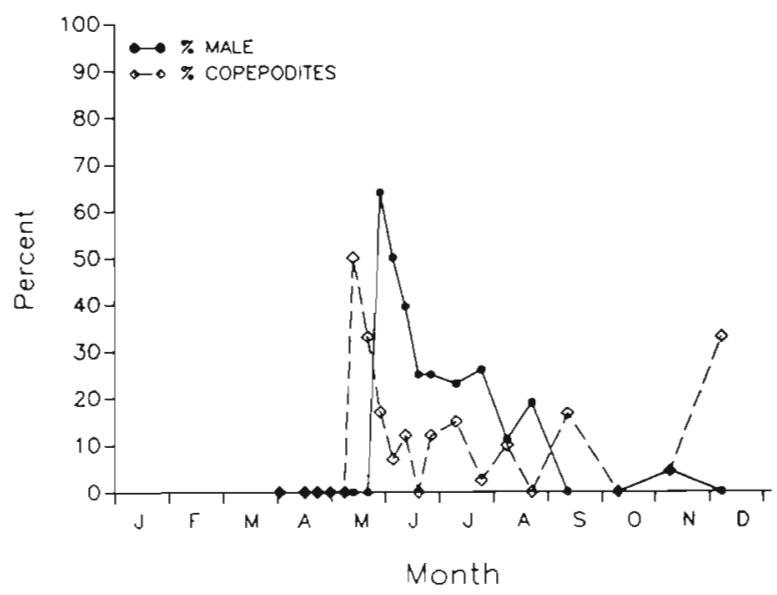

T cf minuta ABM, N 1987

B

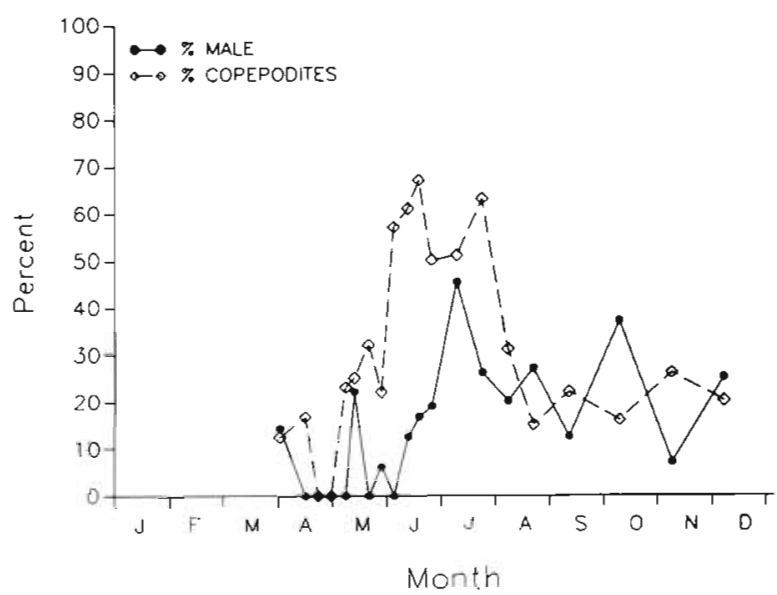

Fig. 6. (A) Danielssenia reducta and (B) Tachidiella cf. minuta. Percent males and percent copepodites at Auke Bay Monitor and North Stations combined in 1987

Pseudameira sp. E 1988

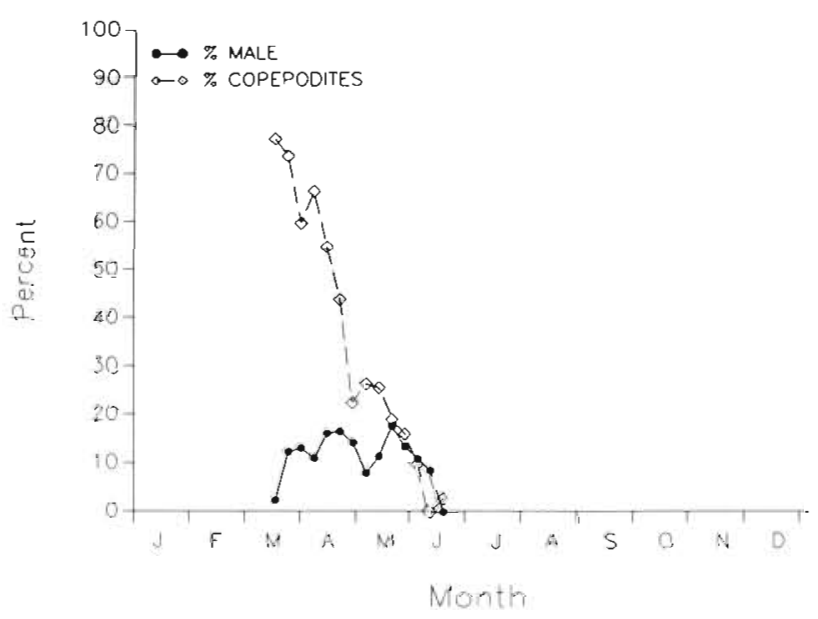

Fig. 7. Pseudameira sp. Percent males and percent copepodites at East Station, 1988 portion of copepodites and males) was coincident with the onset of chl a sedimentation.

Coull \& Dudley (1985) found that the highest density of ovigerous females and copepodites was concurrent with population density peaks for several harpacticoids in South Carolina, USA. Asynchronous hatching and brood development, and non-overlapping cohorts can explain this situation. Coull \& Dudley further suggest that it is unlikely that harpacticoids can be sampled frequently enough to adequately describe demographic patterns. The Alaska environment of Danielssenia reducta and Tachidiella cf. minuta, with cold temperatures, provides favorable conditions to elucidate population dynamics. Slow development and spring reproduction suggest that a single spring cohort was produced, and that weekly sampling was adequate to detect peaks in the proportion of copepodites offet from peaks for males.

Harpacticoid sex ratios vary seasonally in many populations (reviewed by Hicks \& Coull 1983). Hicks \& Coull hypothesized that the proportion of males varies with density, and that increases in males with increasing density may serve as a population density regulating mechanism. Our data suggest, however, that springtime male increases are independent of density and occur only after copepodite increases in Danielssenia reducta and Tachidiella cf. minuta. Densities of $T$. cf. minuta increased concurrently with percent males in 1985, but, in other years and for D. reducta, the increase in males occurred either before population density increased or without density increases.

Several alternative explanations to harpacticoid sex ratio variation exist. The simplest may be that males develop faster than females causing them to be disproportionately represented among the first adults recruited by a cohort. This ensures that mature males will be available to mate with females molting into adulthood. Bergmans (1981) found that males develop about $40 \%$ faster from stage 3 copepodites to adults at $18^{\circ} \mathrm{C}$. However, it seems unlikely that developmental differences alone at Auke Bay's cold temperatures can account for the extreme sex ratio bias (ca $90 \%$ males in Danielssenia reducta; Fig. 4) in early summer. Alternatively, environmental sex determination seems possible for harpacticoids as has been found in other crustaceans (Adams et al. 1987). Marcotte (1983) suggests that sex determination takes place in the naupliar stage, and events during naupliar development might later influence adult sex ratio. Photoperiod has been found to influence sex determination and long daylength, typical for Juneau in May and June, enhances the production of males in amphipods (Naylor et al. 1988) and at least one harpacticoid (Moraitou-Apostolopoulou et al. 1982). Rapid naupliar development rate may also be favorable to male production (Takeda 
1950). Perhaps food availability in Auke Bay regulates development time for Tachidiella cf. minuta and D. reducta. In the spring (with populations dominated by adult females), sedimentation should increase food levels, and combined with warmer temperatures, shorten naupliar development time. The result could be an increase in the proportion of males as the spring nauplii mature. Unfortunately, little is known of the food of nauplii, although Decho \& Fleeger (1988b) suggest that bacteria and mucus associated with diatoms are ingested. Certainly studies of sex determination in harpacticoids need to done to begin to understand variation in sex ratio in natural populations.

Meiofauna appear to have 2 primary food sources involving phytodetritus (Rudnick 1989). Surface feeders (primarily harpacticoids) relatively quickly utilize phytodetritus, and may have rapid responses to sedimentation. Deeper-dwelling meiofauna (e.g. nematodes) probably consume phytodetritus only after it has been buried and incorporated into the detrital loop (Lopez \& Levinton 1987). Although harpacticoids belong primarily to the first group, Rudnick (1989) suggest that some (those of a body form similar to interstitial types) will be less dependent on phytodetritus than others. Bell et al. (1987) used morphology to predict harpacticoid life style, be they phytal, sediment-dwelling or migrating. Based on the first leg (not strongly prehensile), cephalosome area, antennule length and body size (ca $0.5 \mathrm{~mm}$ ), Tachidiella cf. minuta, Danielssenia reducta and Pseudameira sp. would likely classify as sediment-dwellers. Nevertheless there are potential differences among these species. They belong to different families; $T$. cf. minuta to the Tisbidae and $D$. reducta to the Tachidiidae. Species in both families are typically associated with migratory environments and have good colonizing abilities. The Alaskan representatives are modestly robust (Gee 1988). On the other hand, Pseudameira sp. is a very slender species, belonging to the Ameiridae, a group which is often infaunal (Noodt 1971). The vertical distribution of these species is unknown; however it should be noted that Pseudameira sp., the most interstitial-like species from the family most linked to an infaunal existence, was a species with recruitment unrelated to phytodetritus sedimentation.

Many questions remain concerning the relationship between harpacticoid recruitment and sedimentation in Auke Bay. Of the ca 35 species encountered, only 2, albeit predominant species, appear to recruit in conjunction with the sedimentation event. Thus the factors which influence reproduction in the majority of species are still unknown. Although reproduction in Tachidiella cf. minuta and Danielssenia reducta is quite seasonal, neither displayed spring or summer increases in density. Harpacticoid abundance could be tightly regulated due to a number of factors (Fleeger et al. 1989). Further, bloom sedimentation was regular and annually predictable in Auke Bay. This makes it impossible to determine, from our data, if $T$. cf. minuta and $D$. reducta begin reproduction in response to sedimentation or if they have evolved life histories timed to exploit the sedimentation event (the ghost of spring blooms past?). Perhaps only experimental work of food webs and density regulation, either in the laboratory or in controlled mesocosms, can further our understanding of subtidal harpacticoid recruitment.

Acknowledgements. We thank $\mathrm{T}$ Chandler, A. Decho, J. McCall, S. McGregor, L. McNutt, M. Sturdevant, H. Nguyen and $\mathrm{K}$. Welch for sample sorting, with special appreciation to $\mathrm{M}$. Cee for aid in species identifications and for his comments on an earlier manuscript draft. Oceanic Institute (especially D. Ziehmann) provided hydrographic and sedimentation data. D. Erickson and M. Broderson, skippers of the RV 'Maybeso', are thanked for their assistance. The Auke Bay Labs, NMFS, kindly permitted use of their dock facilities. Funding was provided to the Juneau Center for Fisheries, University of Alaska Fairbanks, as part of APPRISE, by the National Oceanic and Atmospheric Administration contract no. NA-85$\mathrm{ABH}-022$.

\section{LITERATURE CITED}

Adams, J., Greenwood, P., Naylor, C. (1987). Evolutionary aspects of environmental sex determination. Int. J. Invert. Repr Dev. 11-123-136

Bell, S. S., Walters, K., Hall, M. O. (1987). Habitat utilization by harpacticoid copepods: a morphometric approach. Mar. Ecol. Prog. Ser. 35: 59-64

Bergmans, M. (1981). A demographic study of the life cycle of Tisbe furcata (Baird, 1837) (Copepoda: Harpacticoida). J mar. biol. Ass. U. K. 61: 691-705

Billett, D. S. M., Lampitt, R. S., Rice, A. L., Mantoura, R. C. F. (1983). Seasonal sedimentation of phytoplankton to the deep-sea benthos. Nature, Lond. 302: 520-522

Carman, K. R., Thistle, D. (1985). Microbial food partitioning by three species of benthic copepods. Mar Biol. 88: $143-148$

Coull, B. C., Dudley, B. W. (1985). Dynamics of meiobenthic copepod populations: a long-term study (1973-1983). Mar. Ecol. Prog. Ser 24: 219-229

Coyle, K. O., Shirley, T C. (1986). A summary of the fisheries and oceanographic research in Auke Bay, Alaska and vicinity. In: APPRISE Annual Report. Summary of 1985 APPRISE Research Program. Univ. of Alaska Juneau, p. $7-142$

Decho, A. W (1986). Water-cover influence on diatom ingestion rates by meiobenthic copepods. Mar. Ecol. Prog. Ser 33: $139-146$

Decho, A. W. (1988). How do harpacticoid grazing rates differ over a tidal cycle? Field verification using chlorophyllpigment analyses. Mar. Ecol. Prog. Ser. 45: 263-270

Decho, A. W., Fleeger, J. W. (1988a). Microscale dispersion of meiobenthic copepods in response to food-resource patchiness. J. exp. mar. Biol. Ecol. 118: 229-244

Decho, A. W., Fleeger, J. W (1988b). Ontogenetic feeding shifts in the meiobenthic harpacticoid copepod Nitocra lacustris. Mar Biol. 97: 191-197 
Fleeger, J. W., Shirley, T. C., Ziemann, D. A. (1989). Meiofaunal responses to an Alaskan spring bloom. I. Major taxa. Mar. Ecol. Prog. Ser. 57: 137-145

Gee, J. M. (1988). Taxonomic studies on Danielssenia (Crustacea, Copepoda, Harpacticoida) with descriptions of two new species from Norway and Alaska. Zool. Scr. 17: 39-53

Gooday, A. J. (1988). A response by benthic Foraminifera to the deposition of phytodetritus in the deep-sea. Nature, Lond. 332: 70-73

Graf, G., Bengtsson, W., Diesner, U., Schulz, R., Theede, H. (1982). Benthic response to sedimentation of a spring phytoplankton bloom: process and budget. Mar. Biol. 67: 201-208

Graf, G., Schulz, R, Peinert, R., Meyer-Reil, L.-A. (1983). Benthic response to sedimentation events during autumn to spring at a shallow-water station in the Western Kiel Bight. I. Analysis of process on a community level. Mar. Biol. 77: 235-246

Grebmeier, J. M., McRoy, C. P., Feder, H. M. (1988). Pelagicbenthic coupling on the shelf of the northern Bering and Chukchi Seas. I. Food supply source and benthic biomass. Mar. Ecol. Prog. Ser. 48: 57-67

Hicks, G. R. F., Coull, B. C. (1983). The ecology of marine meiobenthic harpacticoid copepods. Oceanogr. mar. Biol. A. Rev. 21: $67-175$

Lang, K. (1948). Monographie der Harpacticiden. Otto Koeltz Science Publishers, Lund

Lenz, J. (1977). Seston and its main components. In: Rheinheimer, G. (ed.) Microbial ecology of a brackish water environment. Springer Verlag, Berlin, 39-60

Lopez, G. R., Levinton, J. S. (1987). Ecology of deposit-feeding animals in marine sediments. Q. Rev. Biol. 62: 235-260

Marcotte, B. M. (1983). The imperatives of copepod diversity: perception, cognition, competition and predation. In: Schram, F. R. (ed.) Crustacean phylogeny. A. A. Balkema Publ., Rotterdam, 47-72

Montagna, P. A., Coull, B. C., Herring, T. L., Dudley, B. W. (1983). The relationship between abundances of meiofauna and their suspected microbial food (diatoms and bacteria). Estuar. cstl Shelf Sci. 17: 381-394

Moraitou-Apostolopoulou, M., Verriopoulos, G., Dikaiakou, A. N. (1982). Influence of light conditions of the offspring production and the sex ratio of Tibe holothuriae, Humes (Copepoda, Harpacticoida). Arch. Hydrobiol. 96: 120-127

Naylor, C., Adams, J., Greenwood, P. J. (1988). Variation in sex determination in natural populations of a shrimp. J. evol. Biol. 1: 355-368

This article was presented by Dr R. M. Warwick, Plymouth, United Kingdom
Noodt, W. (1971). Ecology of the Copepoda. In: Hulings, N. C. (ed.) Proceedings of the First International Conference on Meiofauna. Smithsn. Contr. Zool. 76: 97-102

Palmer, M. A. (1984). Invertebrate drift: behavioral experiments with intertidal meiobenthos. Mar. Behav. Physiol. 10: $235-253$

Palmer, M. A., Coull B. C. (1980). The prediction of development rate and the effect of temperature for the meiobenthic copepod, Microarthridion littorale (Poppe). J. exp. mar. Biol. Ecol. 48: 73-83

Pfannkuche, O., Thiel, H. (1987). Meiobenthic stocks and benthic activity on the NE-Svalbard Shelf and in the Nansen Basin. Polar Biol. 7: 253-266

Rudnick, D. T (1989). Time lags between the deposition and meiobenthic assimilation of phytodetritus. Mar. Ecol. Prog. Ser. 50: 231-240

Rudnick, D. T., Elmgren, R., Frithsen, J. B. (1985). Meiofaunal prominence and benthic seasonality in a coastal marine ecosystem. Oecologia (Berl.) 67: 157-168

Shirley, T. C., Fleeger, J. W., Decho, A. W., Sturdevant, M. V (1987). Association of meiofauna with primary production and recruitment in a subarctic ecosystem - 1986. APPRISE Annual Report. Summary of 1986 APPRISE Research Program, Univ. of Alaska Juneau, p. 405-448

Takeda, N. (1950). Experimental studies on the effect of external agencies on the sexuality of a marine copepod. Physiol. Zool. 23: 288-301

Townsend, D. W., Cammen, L. M. (1988). Potential importance of the timing of spring plankton blooms to benthicpelagic coupling and recruitment of juvenile demersal fishes. Biol. Oceanogr. 5: 215-229

Valderhaug, V. A., Gray, J. S. (1984). Stable macrofauna community structure despite fluctuating food supply in subtidal soft sediments of Oslofjord, Norway. Mar. Biol. 82: 307-322

Wells, J. B. J. (1976). Keys to the aid in the identification of marine harpacticoid copepods. Technical paper, Dept of Zoology, Univ. of Aberdeen

Widbom, B., Elmgren, R. (1988). Response of benthic meiofauna to nutrient enrichment of experimental marine ecosystems. Mar. Ecol. Prog. Ser. 42: 257-268

Ziemann, D. A., Conquest, L. D., Bienfang, P. K., Kanda, J. (1988). Patterns of primary production and sedimentation during the 1987 spring bloom in Auke Bay, Alaska. Vol 2. APPRISE Annual Report, SKOS APP87-100, School of Fisheries and Ocean Sciences, University of Alaska, Fairbanks, p. 29-194

Manuscript first received: April 21, 1989

Revised version accepted: October 17, 1989 